\title{
Evaluation of Policy Implementation Admission New Students by Zonation System in Senior High School Bekasi District
}

Fitri Rachmadhany, Matin, Sugiarto

State of Jakarta University, Indonesia

fitriRachmadhany9910818001@mhs.unj.ac.id

\begin{abstract}
This study aim is to evaluate: the condition of the strategic environment of the policy implementation, (2) the process of the policy implementation, and (3) the result of the policy implementation admission of a new student using the zonation system in SMA Negeri Kota Bekasi. The research method is a qualitative evaluation based on the countenance model developed by Stake. Based on research, Preparation for the implementation of the PPDB zoning system policy at SMAN Bekasi City is in a good category. The preparations that have been carried out are quite mature so that they can overcome various problems that arise at the beginning and increase the effectiveness of the implementation of the PPDB zoning system policy. The implementation of the PPDB zoning system policy at SMAN Bekasi City is in a good category. This is based on the fulfillment of the four aspects of the transaction stage in the countenance policy evaluation model. The implementation of the zoning system for the New Student Admissions (PPDB) policy at Bekasi City Public High Schools has positive and negative impacts. This positive impact can be in the form of increased cooperation and coordination between the school and the surrounding community, the faster and easier the problem solving is, the reduced risk that students have to face when traveling to school, the more disciplined students are, and the more open the admission process for new students. The negative impact is on the potential for greater negative environmental influence on students and the difficulty for students outside the school zoning to register, there is a tendency to decline in school academic achievement due to unequal abilities of students, and students tend to decrease in the discipline.
\end{abstract}

Keywords: evaluation, policy of implementation, school admission

Article History Received : August 7th 2020

Revision : October $11^{\text {th }} 2020$

Publication : November $30^{\text {th }} 2020$ 


\section{INTRODUCTION}

The zoning system is a selection system for New Student Admissions (PPDB) by taking into account the distance to where new prospective students live. The objectives of this zoning system include ensuring equal access to educational services for students, bringing the school environment closer to the family environment of students, eliminating discrimination and exclusivity, and helping to calculate the resource needs of educational units.

According to the author's observations in the 2020-2021 school year on the second day of implementing the New Student Admissions (PPDB) with the zoning system, the Bekasi City Education Office was filled with parents of students who filed protests. This is since many errors were found in the location of the coordinate points so that parents could not register at the nearest school. Another problem that occurs in PPDB in Bekasi City is the inadequate use of the zoning quota, which should have been eighty (80) percent, only thirty (30) to forty (40) percent.

Another problem is the existence of several allegations of maladministration such as the absence of standard operating procedures (SOP) for New Student Admission (PPDB), fraud in the form of population administration, complaints about prospective students who are teachers' children who are accepted in a school without going through the Participant Admission mechanism. School admission (PPDB), and there are still requests for money from parents who shouldn't

Some of these problems indicate the need to research on the implementation of the new student admission policy through the zoning system in Bekasi City Public High Schools to find out the problems found as well as to identify aspects that can be developed to determine future policies. By using the Countenance evaluation model developed by Stake, this study compares the suitability of the implementation of the PPDB policy with the zoning system in public high schools in Bekasi City with the policy ideal criteria to assess the success of the policy. This evaluation model emphasizes that in an evaluation it is necessary to have a description (description) and consideration (judgment) about something being evaluated. According to Tyler in Akbar et al (2018), it is stated that evaluation is the process of determining to what extent the educational objectives are actually being realized.

Another definition, evaluation is a process to determine the extent to which educational goals can be realized. Sufflebeam et al (2002) stated that evaluation is generally associated with the assessment of goal achievement. Sufflebeam added that a useful evaluation is an evaluation that provides quality information to make and assess a decision. Scriven in Dwi (2017) explains: evaluation determines the merit, worth, or value of things, the evaluation process identifies relevant values or standards that apply to what is being evaluated, performs empirical investigation 
using techniques from the social sciences, and then integrates conclusions with standards into an evaluation or set of evaluations. Worthen and Sanders in Mami (2018) state that: evaluation is the determination of the worth of thing. It includes obtaining information for use in judging the worth of a program, product, procedure, or objective, or the potential utility of alternative approaches designed to attain specified objectives.

The focus of the research is the preparation for the implementation of the PPDB Zoning policy at the Bekasi City Public High School, the implementation of the PPDB Zoning policy at the Public High Schools in Bekasi City, and the impact of the implementation of the PPDB Zoning policy for the Bekasi City Public Senior High School. This study aims to determine the conditions for the preparation of the implementation of the PPDB zoning system policy in Bekasi City Public High Schools, the process of implementing the PPDB zoning system policy in Bekasi City Public High Schools, and the impact of implementing the zoning system PPDB policy in Bekasi City Public High Schools. Dye in Abidin (2012) mentions policy as the government's choice to do something. In line with that, Hasbullah (2015) argues that public policy is any decision made by the state as a strategy to realize the goals of the state. Rose in Hamdi (2014) defines policy not just as a decision but as a long process of several activities that are related and have consequences for those concerned. Meanwhile, Asiyah et al. (2017) wrote that public policy is a process of formulation, implementation and evaluation of policies that are continuous and interrelated, which is carried out by the government and stakeholders in managing and resolving various public affairs, public problems and existing resources for the benefit public.

Van Meter and Van Horn in Rusdiana (2015) reveal that policy implementation is the whole action taken by individuals or groups to achieve specified goals. Reinforcing the previous opinion, Lester \& Stewart in Rawita (2013) stated that policy implementation means policy implementation in which various actors, organizations, procedures, and techniques work simultaneously to achieve policy goals.

Grindle in Rusdiana (2015) states that policy implementation is not only limited to the mechanism of elaborating political decisions but also related to issues of interest in a policy. In line with that, Imron in Pangaribun and Hariyati (2019) states that policy implementation is the actualization of educational policies in real terms in the field. Meanwhile, according to Quad in Pangaribuan and Hariyati (2019) in policy implementation, there will be interactions and reactions from a group of implementers, target groups, and environmental factors that cause pressure to emerge and are followed by transaction actions. The transaction that is meant by Quad is a response that will become feedback which will then be used in the next policy formulation. 
Based on the opinions of the experts above, policy implementation is a series of processes that involve individuals or groups who are responsible for implementing policies but also involve groups of policy creators in the field which can directly or indirectly affect all parties involved and ultimately affect the impact. both the expected and the unexpected.

Researchers will conduct research that focuses on evaluating the implementation of PPDB policies with the zoning system in public high schools in Bekasi City. The difference with previous studies is in terms of research background, research focus, evaluation model used, and research object.

The evaluation model used is Countenance and according to Stake is the whole. This evaluation model emphasizes the implementation of two things that are the main points in evaluation, namely description and consideration. This model distinguishes three stages in evaluation, namely antecedents, transactions, and outputs. This model is described as follows:

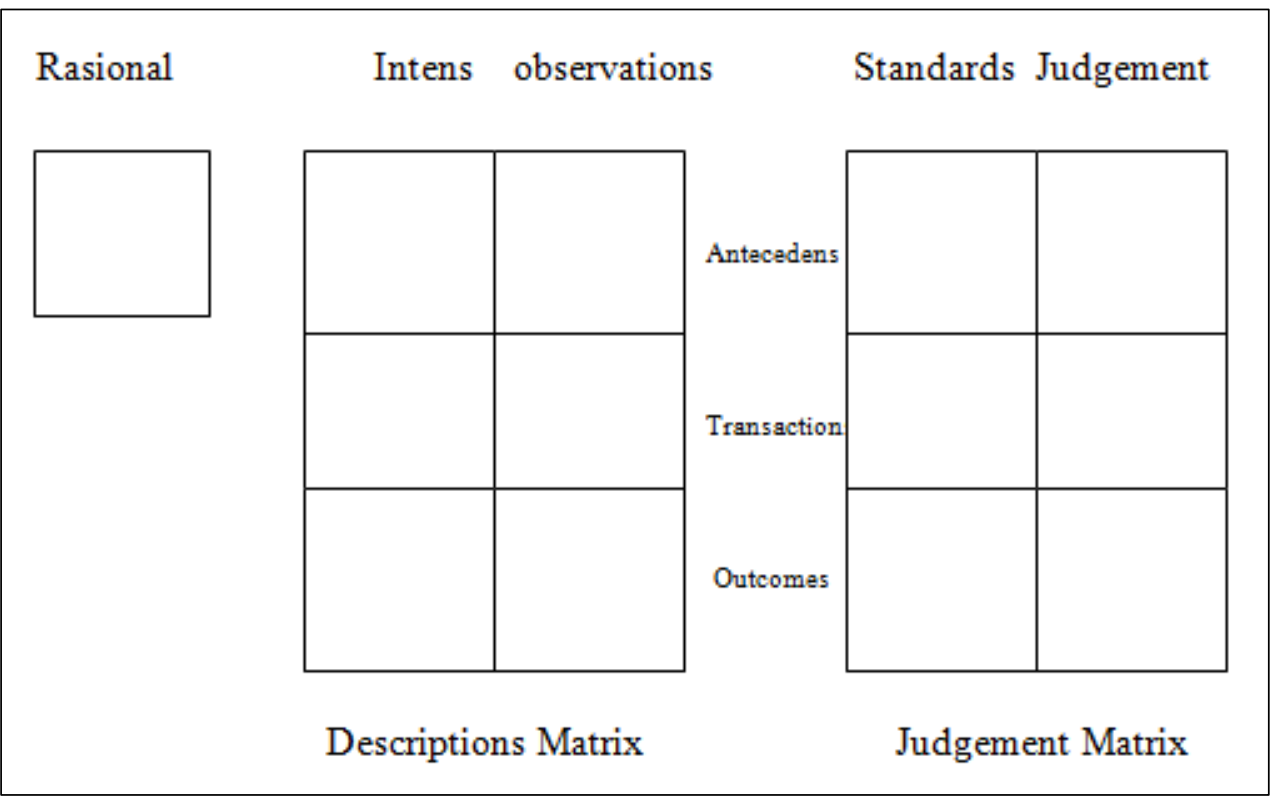

Figure 1. Evaluation Model of Countenance Stake in Arikunto (2014)

Each matrix consists of two elements and three parts. The description matrix consists of intents (objectives) and observations (observations). After the description matrix is completed the evaluator moves to the judgment matrix which consists of standard and judgment elements so that a decision is finally obtained. According to Stake, a formal evaluation must pay attention to the circumstances before a policy is implemented, during the implementation process, and relate it to the impact. Stake thinking is known as anti-trend, transactions, and outcomes. PPDB policy regulations for Public Senior High Schools in Bekasi City are stipulated by Governor Regulation Number 16 of 2019 concerning guidelines for the Admission of New High School, Vocational School, and SLB Students in West Java. 
Based on the Government Rules, for PPDB SMA there are three PPDB lines provided. First, the zoning route with a quota of 90 percent, consisting of 55 percent of the full distance, 20 percent of the economically disadvantaged family (KETM), and a combination of distance and academic achievement of 15 percent. Second, the achievement path with a 5 percent quota. The track of achievement in question can be in the form of UN achievements or non-UN achievements. Third, the path of moving parents with a quota of 5 percent is based on transferring tasks or following the workplaces of the prospective students' parents.

In implementing PPDB, prospective students who register at the SMA, SMK, and SLB education units organized by the West Java Provincial Government are free of registration fees. PPDB is done online through the Web-based PPDB application. Prospective students register through the intended school and follow the registration mechanisms and requirements that have been determined. As for the announcement of the election results online, it will be submitted to the school to be determined by each school.

Each matrix consists of two elements and three parts. The description matrix consists of intents and observations. After the description matrix is completed the evaluator moves to the judgment matrix which consists of standard and judgment elements so that a decision is finally obtained.

\section{METHOD}

This type of research is a descriptive study using a qualitative approach. This type of descriptive research according to Moloeng (2017) is a research procedure that produces descriptive data in the form of written words or is the utterance of the people being observed. This study uses a qualitative approach because the data collected in the field are data in the form of words or behavior, sentences and natural pictures, humans as instruments. Then the data is used to describe and explain the social phenomena that were studied in SMA Negeri in Bekasi City. To optimize research activities, researchers limited research to 5 (five) schools contained in Sub District 02, namely SMA Negeri 4, 10, 12, 14, and 20. The selection of Sub District 02 in this study was to pay attention to the affordability of the research location by the researcher.

Data collection techniques are as follows: interviews, Documentation Studies, and Observations (observations). According to Milles and Huberman in Sugiyono, (2016) there are three components of data analysis, namely (1) Data reduction, namely selecting and summarizing the data obtained and then focusing on matters relating to the implementation of zoning system policies in the Admission of New Students (PPDB) in Public SMA in Bekasi City, (2) Presentation of data. In qualitative research, data presentation can be done in the form of a brief description; charts, relationships between categories, flowcharts, and the like. 
According to Miles and Huberman in Sugiyono (2015), it is stated that the most frequently present data in qualitative research is a narrative text, (3) concluding or verification. In table 1 below, there is a grid of research instruments.

Table 1. Grid of Research Instruments for Evaluation of PPDB Policy Implementation with the Zoning System in Bekasi City Public High Schools

\begin{tabular}{|c|c|c|c|c|}
\hline Number & $\begin{array}{l}\text { Komponen } \\
\text { Evaluasi }\end{array}$ & $\begin{array}{l}\text { Sub Component } \\
\text { Evaluation }\end{array}$ & $\begin{array}{c}\text { Criteria } \\
\text { Evaluation } \\
\text { Instrument }\end{array}$ & Instrument \\
\hline \multirow[t]{4}{*}{1.} & $\begin{array}{l}\text { Antecendent } \\
\text { (Initial } \\
\text { Conditions) }\end{array}$ & $\begin{array}{l}\text { a. Availability of } \\
\text { Facilities and } \\
\text { Infrastructure }\end{array}$ & $\begin{array}{l}\text { Policy objectives are } \\
\text { clearly defined }\end{array}$ & $\begin{array}{l}\text { Documentation } \\
\text { and interviews }\end{array}$ \\
\hline & & $\begin{array}{l}\text { b. Availability of } \\
\text { Fees }\end{array}$ & $\begin{array}{l}\text { Policy Objectives for } \\
\text { All Schools to } \\
\text { implement PPDB } \\
\text { with a Zoning } \\
\text { System in } \\
\text { accordance with the } \\
\text { policies }\end{array}$ & $\begin{array}{l}\text { Documentation } \\
\text { and interviews }\end{array}$ \\
\hline & & $\begin{array}{l}\text { c. Policy } \\
\text { implementation } \\
\text { planning }\end{array}$ & $\begin{array}{lr}\text { Availability of } \\
\text { facilities } \\
\text { infrastructure }\end{array}$ & $\begin{array}{l}\text { Documentation } \\
\text { and interviews }\end{array}$ \\
\hline & & $\begin{array}{ll}\text { d. } & \text { Policy } \\
& \text { Implementation } \\
\end{array}$ & $\begin{array}{l}\text { Availability of a } \\
\text { budget }\end{array}$ & $\begin{array}{l}\text { Documentation } \\
\text { and interviews }\end{array}$ \\
\hline \multirow[t]{4}{*}{2.} & Transaction & $\begin{aligned} \text { a. } & \text { Supervision of } \\
& \text { Policy } \\
& \text { Implementation }\end{aligned}$ & $\begin{array}{l}\text { Implementation } \\
\text { planning is } \\
\text { compiled based on } \\
\text { regulations }\end{array}$ & $\begin{array}{l}\text { Documentation } \\
\text { and interviews }\end{array}$ \\
\hline & & b. Policy Evaluation & $\begin{array}{l}\text { Implementation of } \\
\text { policies according } \\
\text { to planning }\end{array}$ & $\begin{array}{l}\text { Documentation } \\
\text { and interviews }\end{array}$ \\
\hline & & c. Policy Results & $\begin{array}{l}\text { The existence of } \\
\text { monitoring of policy } \\
\text { implementation }\end{array}$ & $\begin{array}{l}\text { Documentation } \\
\text { and interviews }\end{array}$ \\
\hline & & $\begin{array}{l}\text { d. Achievement of } \\
\text { goals for } \\
\text { improvement }\end{array}$ & $\begin{array}{l}\text { There is an } \\
\text { evaluation of policy } \\
\text { implementation }\end{array}$ & $\begin{array}{l}\text { Documentation } \\
\text { and interviews }\end{array}$ \\
\hline 3. & Outcomes & $\begin{array}{ll}\text { a. } & \text { Availability of } \\
\text { Facilities and } \\
\text { Infrastructure }\end{array}$ & $\begin{array}{l}\text { Policy outcomes are } \\
\text { in accordance with }\end{array}$ & $\begin{array}{l}\text { Documentation } \\
\text { and interviews }\end{array}$ \\
\hline
\end{tabular}




\begin{tabular}{|l|l|l|l|}
\hline & & $\begin{array}{l}\text { objectives and } \\
\text { planning }\end{array}$ & \\
\hline & $\begin{array}{l}\text { b. Availability of } \\
\text { Fees }\end{array}$ & $\begin{array}{l}\text { There is the } \\
\text { achievement of } \\
\text { goals for further } \\
\text { improvement. }\end{array}$ & $\begin{array}{l}\text { Documentation } \\
\text { and interviews }\end{array}$ \\
\hline
\end{tabular}

Evaluation model used as a reference is the Countenance evaluation model initiated by Stake. The model is quite comprehensive so that it fits the needs of policy evaluation which is complex and dynamic. According to the Countenance evaluation model, a formal evaluation must pay attention to the situation before a policy is implemented, during the implementation process, and relate it to the results. The three coverage aspects of evaluation are known as anti-trends, transactions, and outcomes (Arikunto, 2014).

\section{RESULTS AND DISCUSSION}

Research Results SMAN 4 Bekasi implements a PPDB zoning system. Under the policy of the West Java provincial government. The public can find out information about PPDB at SMAN 4 Bekasi by accessing the West Java Provincial Education Office website with the link https://ppdb.disdik.jabarprov.go.id/
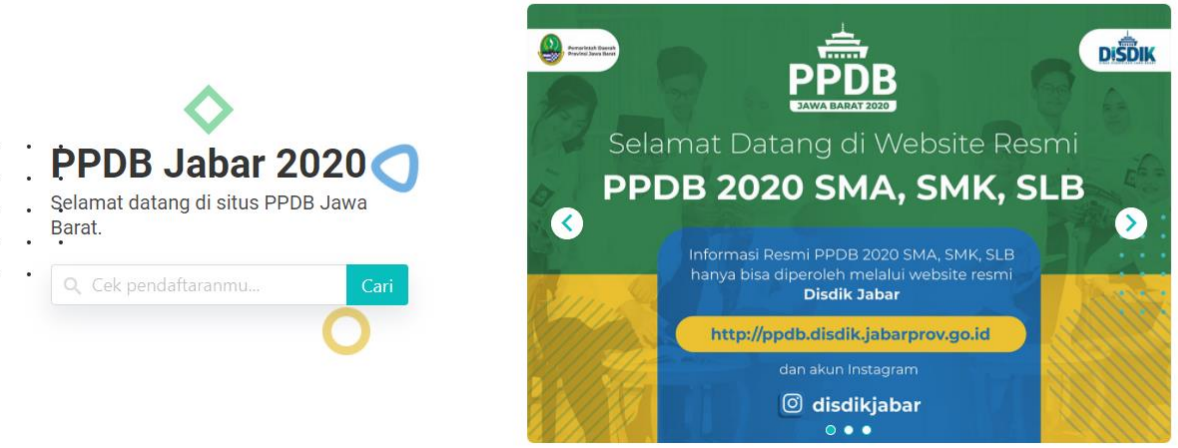

Figure 2. Website for Access to PPDB Information at SMAN 4 Bekasi

The following is data about the school environment, which includes data on Teachers and Educators employment data on Students.

Table 2. Data on Teachers, Educators, and Students at SMAN 4 Bekasi

\begin{tabular}{|c|l|c|c|c|c|}
\hline Number & Description & Teachers & Educator Employ & Total & Students \\
\hline 1 & Male & 19 & 18 & 37 & 449 \\
\hline 2 & Female & 31 & 7 & 38 & 652 \\
\hline \multicolumn{2}{|c|}{ TOTAL } & $\mathbf{5 0}$ & $\mathbf{2 5}$ & $\mathbf{7 5}$ & $\mathbf{1 1 0 1}$ \\
\hline
\end{tabular}

SMAN 10 Bekasi is located on Jalan Flamboyan Raya Perum Harapan Indah, Medan Satria District, Bekasi City, West Java Province. The local government-owned school 
was established based on the Decree No. 451.2 / 522 / Sosial which was issued on May 9, 1997. The school operation was determined through Decree No. 046 / 0 / 2001 with the school's operational date being 17th April 2001.

In order to implement PPDB in accordance with PPDB Technical Guidelines at 2020 High School in West Java Province, SMAN 10 has prepared online media in the form of a website that can be accessed on the official website of SMAN 10, namely at the link https://sman10kotabekasi.sch.id/page/cek ppdb\#. Prospective students guardians can access the link to find out registration announcements.

(i) SMA NEGERI 10

KOTA BEKASI

BERANDA PROFIL - BERITA GALERI- EKSKUL SISTEMINFORMASI- PPDB SMARTREN

\section{Pengumuman PPDB SMAN 10 Kota Bekasi}

Silakan Masukan Nomor Pendaftaran Anda pada form yang disediakan.

BANNER

PERGURUAN TINGGI

$H: 80 \mathrm{PX}, \mathrm{W}: 230 \mathrm{PX}$

Figure 3. Website of SMAN 10 Bekasi

The following is data regarding the school environment, which includes data for Teachers and Educators employment, and student data at SMAN 10 Bekasi:

Table 2. Data on Teachers, Educators, and Students at SMAN 10 Bekasi

\begin{tabular}{|c|c|c|c|c|c|}
\hline Number & Description & Teacher & Educator Employ & Total & Student \\
\hline 1 & Male & 19 & 11 & 30 & 478 \\
\hline 2 & Female & 35 & 8 & 43 & 549 \\
\hline \multicolumn{2}{r|}{ TOTAL } & $\mathbf{5 4}$ & $\mathbf{1 9}$ & $\mathbf{7 3}$ & $\mathbf{1 0 2 7}$ \\
\hline
\end{tabular}

In order to facilitate PPDB online, SMAN 12 Bekasi has a website that can be accessed by prospective students and prospective student guardians to find out about PPDB announcements at SMAN 12 Bekasi. The link from the website is https://www.sman12-bekasi.sch.id/penglikasi-ppdb. 


\section{Masukkan nomor pendaftaran kamu disini}

input hanya digit angka saja

The following is data regarding the school environment, which includes data for Teachers and Educators employment, and student data at SMAN 12 Bekasi:

Table 4. Data on Teachers, Educators, and Students at SMAN 12 Bekasi

\begin{tabular}{|c|l|c|c|c|c|}
\hline Number & Description & Teacher & Educator Employ & Total & Student \\
\hline 1 & Male & 17 & 5 & 22 & 355 \\
\hline 2 & Female & 20 & 4 & 24 & 651 \\
\hline \multicolumn{2}{|c|}{ TOTAL } & $\mathbf{3 7}$ & $\mathbf{9}$ & $\mathbf{4 6}$ & $\mathbf{1 0 0 6}$ \\
\hline
\end{tabular}

In contrast to SMAN 10 and SMAN 12 which have features on the school website that can be accessed by prospective students and prospective student guardians to find out PPDB information, SMAN 14 directs access for this information to the West Java Education Office website. The link from the website is https://sekolah.ppdb.disdik.jabarprov.go.id/login

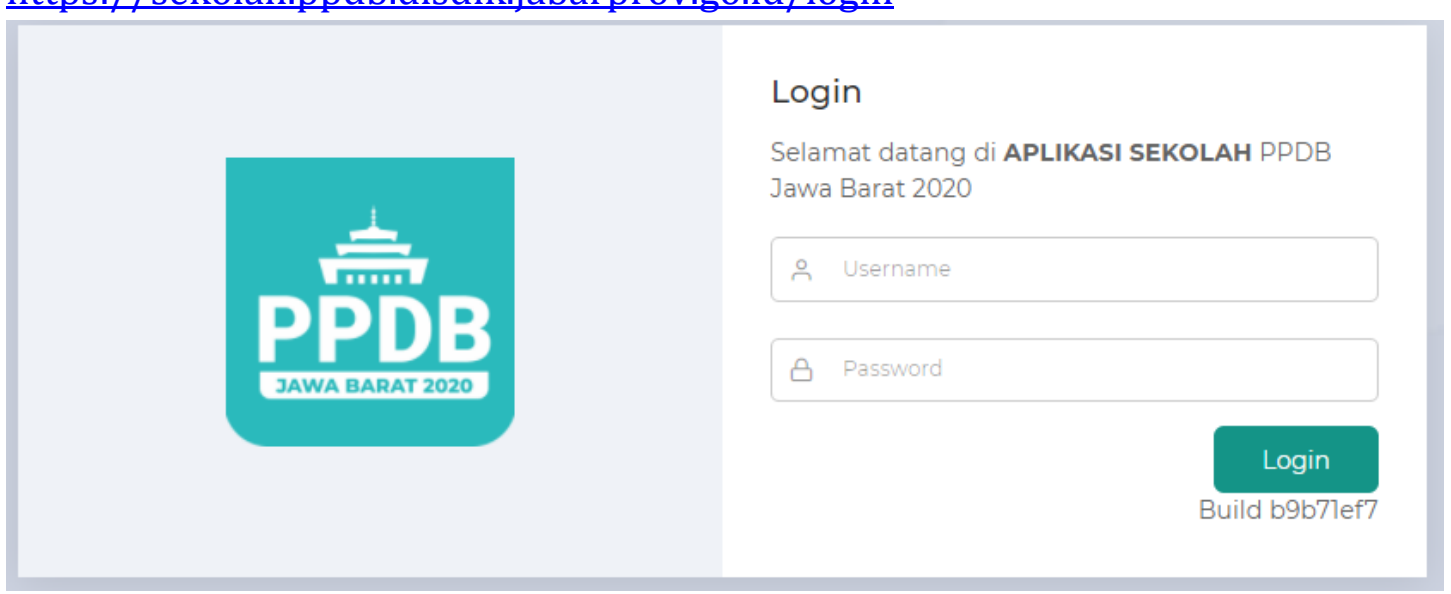

Figure 5. Information Access for PPDB SMAN 14 Bekasi

The following is data regarding the school environment, which includes data for Teachers and Educators, and Student data at SMAN 14 Bekasi:

Table 5. Data on Teachers, Educators, and Students at SMAN 14 Bekasi

\begin{tabular}{|c|l|c|c|c|c|}
\hline Number & Description & Teacher & Educator Employ & Total & Student \\
\hline 1 & Male & 11 & 11 & 22 & 506 \\
\hline 2 & Female & 29 & 2 & 31 & 723 \\
\hline
\end{tabular}




\begin{tabular}{|c|c|c|c|c|c|}
\hline Number & Description & Teacher & Educator Employ & Total & Student \\
\hline \multirow{2}{*}{ TOTAL } & 40 & 13 & 53 & 1229 \\
\hline
\end{tabular}

The SMAN 20 website does not have a simple PPDB result checking feature such as SMAN 10 and SMAN 12, nor does it point to the West Java Education Office website. However, SMAN 20 uses google drive facilities to convey PPDB selection information with a link

https://drive.google.com/file/d/1EwBmn1zGvf9f37U06MeSq0F xuUYK9 R/view? usp=sharing

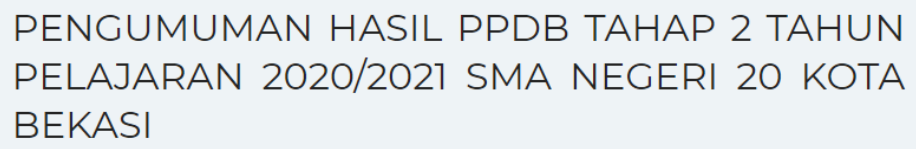

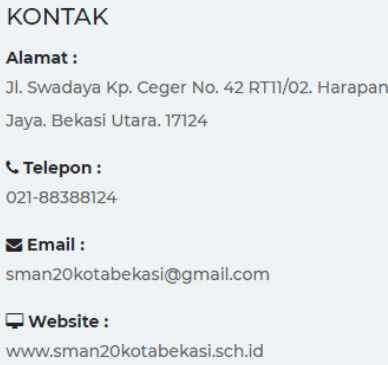

The following is data regarding the school environment, which includes data for Teachers and Educators, and Student data at SMAN 20 Bekasi:

Table 6. Data on Teachers, Educators, and Students at SMAN 20 Bekasi

\begin{tabular}{|c|l|c|c|c|c|}
\hline Number & Description & Teacher & Educator Employ & Total & Student \\
\hline 1 & Male & 6 & 4 & 10 & 170 \\
\hline 2 & Female & 11 & 2 & 13 & 216 \\
\hline \multicolumn{2}{|c|}{ TOTAL } & $\mathbf{1 7}$ & $\mathbf{6}$ & $\mathbf{2 3}$ & $\mathbf{3 8 6}$ \\
\hline
\end{tabular}

Based on the analysis of the results of interviews with research informants regarding the impact of the implementation of the PPDB zoning system policy at SMAN Bekasi above, a matrix of analytical findings can be prepared as follows:

Tabel 7. Matriks Temuan Analisis terhadap Dampak Implementasi Kebijakan PPDB Sistem Zonasi di SMAN Kota Bekasi 


\begin{tabular}{|c|c|c|c|c|c|c|}
\hline $\begin{array}{l}\text { Evaluation } \\
\text { Component }\end{array}$ & SMAN 4 & SMAN 10 & SMAN 12 & SMAN 14 & SMAN 20 & Result \\
\hline Policy Result & $\begin{array}{l}\text { - The school has a } \\
\text { positive and } \\
\text { negative impact } \\
\text { - The positive } \\
\text { impact will be in } \\
\text { the form of } \\
\text { increased } \\
\text { cooperation and } \\
\text { coordination } \\
\text { between schools } \\
\text { and communities, } \\
\text { as well as } \\
\text { increased } \\
\text { community } \\
\text { support for } \\
\text { school programs } \\
\text { - The negative } \\
\text { impact is in the } \\
\text { form of a } \\
\text { tendency to } \\
\text { decrease the } \\
\text { quality or } \\
\text { academic }\end{array}$ & 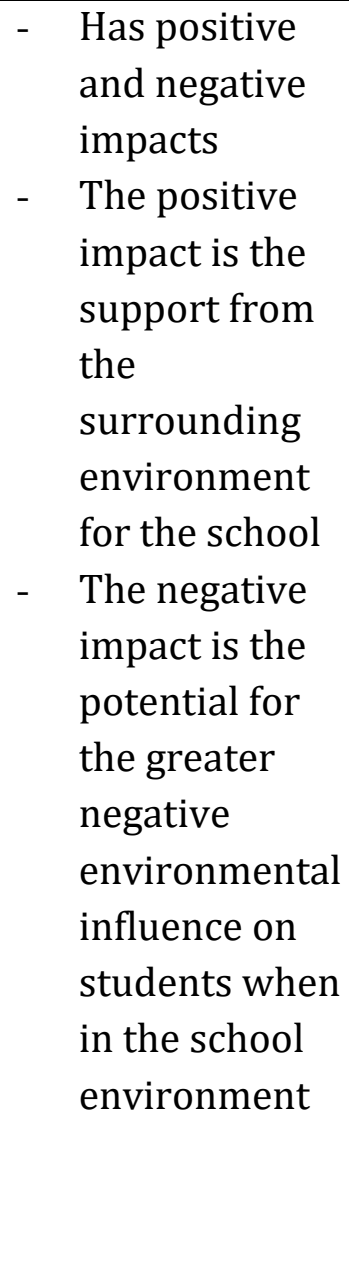 & $\begin{array}{l}\text {-The school has } \\
\text { positive and } \\
\text { negative impacts } \\
\text {-The positive } \\
\text { impact of } \\
\text { implementing } \\
\text { the PPDB zoning } \\
\text { system policy is } \\
\text { the increased } \\
\text { cooperation and } \\
\text { coordination } \\
\text { between schools } \\
\text { and the } \\
\text { surrounding } \\
\text { community, } \\
\text { reduced risk of } \\
\text { students } \\
\text { traveling to } \\
\text { school, and } \\
\text { faster problem } \\
\text { solving } \\
\text { processes }\end{array}$ & 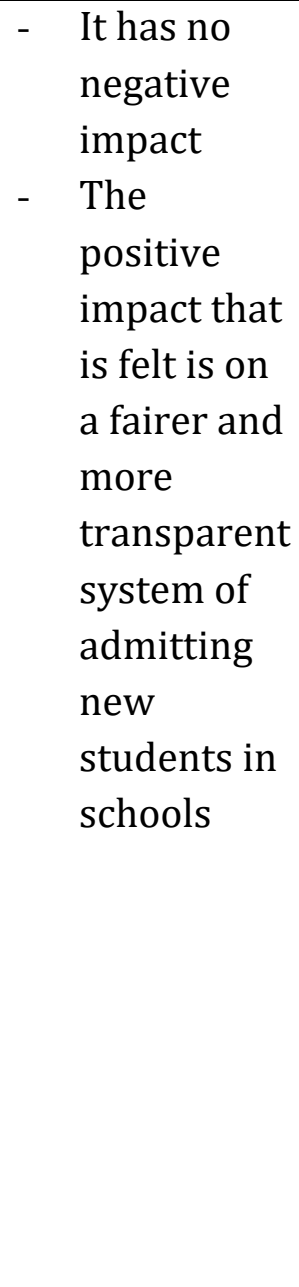 & 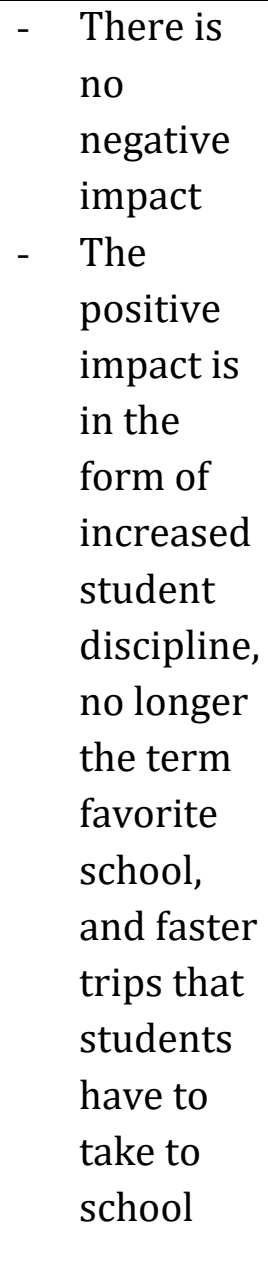 & $\begin{array}{l}\text { The implementation of the } \\
\text { zoning system PPDB policy } \\
\text { has positive and negative } \\
\text { impacts. This positive } \\
\text { impact can be in the form } \\
\text { of increased cooperation } \\
\text { and coordination between } \\
\text { the school and the } \\
\text { surrounding community, } \\
\text { the faster and easier the } \\
\text { problem solving is, the } \\
\text { reduced risk that students } \\
\text { have to face when traveling } \\
\text { to school, the more } \\
\text { disciplined students are, } \\
\text { and the more open the } \\
\text { admission process for new } \\
\text { students. The negative } \\
\text { impact is the potential for } \\
\text { greater negative } \\
\text { environmental influences } \\
\text { on students, difficulties for } \\
\text { students outside the school }\end{array}$ \\
\hline
\end{tabular}




\begin{tabular}{|c|c|c|c|c|c|c|}
\hline $\begin{array}{l}\text { Evaluation } \\
\text { Component }\end{array}$ & SMAN 4 & SMAN 10 & SMAN 12 & SMAN 14 & SMAN 20 & Result \\
\hline & $\begin{array}{l}\text { achievement of } \\
\text { the school due to } \\
\text { the uneven ability } \\
\text { of students, as } \\
\text { well as the } \\
\text { tendency of } \\
\text { students to } \\
\text { decline in } \\
\text { discipline }\end{array}$ & & $\begin{array}{l}\text { - The negative } \\
\text { impact of } \\
\text { implementing } \\
\text { the PPDB zoning } \\
\text { system policy is } \\
\text { on students who } \\
\text { are outside any } \\
\text { school zone, who } \\
\text { will have } \\
\text { difficulty } \\
\text { registering }\end{array}$ & & & $\begin{array}{l}\text { zoning to register, there is } \\
\text { a tendency to decline in } \\
\text { school academic } \\
\text { achievement and decrease } \\
\text { student discipline. }\end{array}$ \\
\hline
\end{tabular}


Volume 4 Number 2 December 2020

\begin{tabular}{|c|c|c|c|c|c|c|}
\hline $\begin{array}{c}\text { Evaluation } \\
\text { Component }\end{array}$ & SMAN 4 & SMAN 10 & SMAN 12 & SMAN 14 & SMAN 20 \\
\hline & & & & $\begin{array}{l}\text { automatically } \\
\text { locked }\end{array}$ & Result \\
\hline
\end{tabular}




\section{Discussion}

The application of the zoning system will encourage more equitable PPDB implementation, while at the same time reducing costs, time, and following the objectives of equitable access and quality of education. Through the zoning system, education is carried out by getting closer to the community because the majority of students come from the environment around the school (Perdana, 2019; Purwanti et al, 2018).

Based on the results of the data analysis in the previous section, it can be seen that the four SMANs in Bekasi which are the objects of this research have sufficient preparation to implement the PPDB zoning system by government regulations. PPDB committees and teachers who teach at SMAN 10, 12, 14, and 20 have an understanding of the objectives of the PPDB zoning system policy because of the intense socialization carried out by the government and coordination between SMA and SMP. Besides, the school also provides documents related to PPDB policies along with technical guidelines from the government, so that both the committee and teachers understand the contents and objectives of implementing the PPDB zoning system in the Bekasi City area.

Socialization is carried out in various ways, from meetings, interactions using VCOM, to utilizing digital media such as social media and websites. Thus, it is not only the internal environment of educational institutions that can know PPDB policies, but also the wider community. Clearly defined policy objectives are an important aspect of the policy implementation preparation phase. According to Purwanti et al. (2019), with clarity on the objectives to be achieved, the PPDB executing committee can carry out their duties in a directed manner, thereby increasing the likelihood of achievement of policy goals.

The results of data analysis also show that all SMANs that are the object of this study have implemented the PPDB zoning system. The implementation of the PPDB policy did experience various problems at the beginning, but due to the preparation and availability of adequate infrastructure, these problems can be resolved properly.

The third stage of the countenance policy evaluation model is an outcomes stage that analyzes two aspects consisting of policy results and achieving goals for improvement. Policy results are related to the impacts obtained from policy implementation. These impacts can be in the form of positive or negative impacts. The implementation of the zoning system PPDB policy has positive and negative impacts. This positive impact can be in the form of increased cooperation and coordination between the school and the surrounding community, the faster and easier the problem solving is, the reduced risk that students have to face when traveling to school, the more disciplined students are, and the more opening up the process of admitting new students. The negative impact is the potential for the 
greater negative environmental influence on students and the difficulty for students who are outside the school zoning to register.

The positive impact of implementing the PPDB zoning system policy at SMAN in Bekasi is in line with the findings of research by Nurlailiyah (2019) which states that there are three positive impacts of implementing the PPDB zoning system policy, namely, first, students with the highest achievement are expected to be able to motivate other students as well as students. with good behavior can infect others. Second, the more competent the teacher will be able to improve student learning, the more competent the teacher is, the more competent the teacher is assigned to teach low-achieving students. Third, equitable quality education, children have the same opportunity to access quality education.

The negative impacts found by Nurlailiyah (2019) are different from this research. According to Nurlailiyah (2019), the implementation of the PPDB zoning system policy will cause students with below-average abilities to find it difficult to follow high-achieving student learning. Conversely, intelligent students must slow down their learning to accommodate other students

The reality that the offline PPDB mechanism cannot be separated is also found by Wardhana \& Supriyoko (2019), that even though the PPDB zoning system has been directed to be implemented online, in practice there is still an offline mechanism in PPDB. This is due to confusion over data input between the registrant independently and the school of origin, so that registration must be carried out offline to ensure there is no duplicate data. In other words, the offline mechanism in the PPDB zoning system that has been directed to be implemented online is the result of an imperfect system, which allows for multiple data input.

\section{CONCLUSION}

Preparation for the implementation of the PPDB zoning system policy at SMAN Bekasi City is in a good category. This is based on the fulfillment of the four aspects of the initial condition (antecedent) in the Countenance evaluation model. The preparations that have been carried out are quite mature so that they can overcome various problems that arise at the beginning and increase the effectiveness of the implementation of the PPDB zoning system policy.

The implementation of the PPDB zoning system policy at SMAN Bekasi City is in a good category. This is based on the fulfillment of the four aspects of the transaction stage in the countenance policy evaluation model. Bekasi City Senior High School has careful planning, can implement the PPDB zoning system policy according to the plan, implement supervision during the implementation process, and evaluate each end of the PPDB implementation.

The implementation of the zoning system for the New Student Admissions (PPDB) policy at Bekasi City Public High Schools has both positive and negative 
impacts. This positive impact can be in the form of increased cooperation and coordination between the school and the surrounding community, the faster and easier the problem solving is, the reduced risk that students have to face when traveling to school, the more disciplined students are, and the more opening up the process of admitting new students. The negative impact is the potential for greater negative environmental influence on students and the difficulty for students outside the school zoning to register, there is a tendency to decline in school academic achievement due to unequal abilities of students, and students tend to decline in discipline.

\section{REFERENCES}

Akbar, M. (2016). Evaluasi Kebijakan Pemberian Dana Bantuan Operasional Sekolah. Jurnal Kebijakan Analisis dan Pelayanan Publik Volume 2 Nomor 1, 47-64.

Akbar, M. F., \& Mohi, W. (2018). Studi Evaluasi Kebijakan. Gorontalo: Ideas Publishing.

Ardiyansyah, A., \& Kristyaningrum, D. H. (2019). Evaluasi Program Penerimaan Peserta Didik Baru (PPDB) Sistem Zonasi di Kabupaten Brebes menggunakan model CIPP. Jurnal Dialektika PGSD, 186-195.

Arikunto, S., \& Jabar, C. S. (2014). Evaluasi Program Pendidikan. Jakarta: Bumi Aksara.

Asiyah, S. (2017). Evaluasi Implementasi Kebijakan Pendidikan Gratis Di Kabupaten Pasaman. Journal of Public Sector Innovation, Vol 2.

Deswary, D. (2017). Evaluasi Implementasi Kebijakan No. 12 Tahun 2012 Tentang Tuntutan Pengelolaan Kurikulum. Jurnal Manajemen Pendidikan Volume 8 Nomor 1.

Hajaroh, M. (2018). Pohon Teori Evaluasi Kebijakan dan Program. Foundasia, 27-42.

Hamdi, M. (2014). Kebijakan Publik : Proses, analisis, dan partisipasi. Ghalia Indonesia.

Hasbullah. (2015). Kebijakan Pendidikan (Dalam Perspektif Teori, Aplikasi, dan Kondisi Objektif Pendidikan di Indonesia). Jakarta: Rajawali Pers.

Hasbullah, S. A. (2019). Evaluasi Kebijakan Sistem Zonasi Dalam Penerimaan Peserta Didik Baru (PPDB) Di Tingkat Sekolah Menengah Pertama Negeri (SMPN) Di Kabupaten Pamekasan. Jurnal Ilmiah Ilmu Sosial dan Ilmu Politik, Vol 9 No 2.

Hoerudin, C. W. (2019). Evaluation Of New Student Admission Policy Based On Zonation System In Bandung City. JISPO Vol 9 No 2 , 351-361.

Moloeng, L. (2017). Metode Penelitian Kualitatif. Bandung: Remaja Rosdakarya. 
Pangaribuan, E., \& Hariyati, N. (2019 Vol 7 No 1). Implementasi Kebijakan Sistem Zonasi PPDB jenjang SMP di Gresik. Inspirasi Manajemen Pendidikan, 1-12.

Parson, W. (2017). Policy Public :Pengantar Teori dan praktik analisis kebijakan. Jakarta: KEncana.

Perdana, N. S. (2019). Implementasi PPDB Zonasi Dalam Upaya Pemerataan Akses dan Mutu Pendidikan. Jurnal Pendidikan Glasser, 78-92.

Purwanti, D., Irawati, I., \& Adiwisastra, J. (2018). Efektivitas Kebijakan Penerimaan Peserta Didik Baru Sistem Zonasi Bagi Siswa Rawan Melanjutkan Pendidikan. Jurnal Ilmiah Ilmu Administrasi Negara Vol 5 No 4, 1-7.

Rawita, \& Sutisno, I. (2013). Kebijakan pendidikan Teori Implementasi dan Monev. Yogyakarta: Kurnia Kalam Semesta.

Rawita, I. S. (2013). Kebijakan Pendidikan Teori Impementasi dan Monev. Yogyakarta: Kurnia Kalam Semesta.

Rusdiana, A. (2015). Kebijakan Pendidikan Dari Filosofi Ke Implementasi. Bandung: Pustaka Setia.

Rusli, B. (2015). Kebijakan Publik Membangun Pelayanan Publik yang responsif. Bandung: CV. Adoya Mitra Sejahtera.

Safarah, A., \& Wibowo, U. (2018). Program Zonasi di Sekolah Dasar Sebagai Upaya Pemerataan Kualtas Pendidikan di Indonesia. Lentera Pendidikan Vol 21 No 2, 206-213.

Schwartz, e. (2014). Inclusionary Zoning Can Bring Poor Families Closer to Good School. Policy Brief "How Housing Matters" pada macfound.org/housingmatters.

Sufflebeam, Madaus, G., \& Kellaghar, T. e. (2002). Evaluation Models; Viewpoint on Educational and Human Services Evaluation. New York: Kluwer Academic Publisher.

Sugiyono. (2016). Metode penelitian kuantitatif dan kualitatif. Bandung: Alfabeta.

Suharno. (2013). Dasar-dasar kebijakan publik. Yogya: Penerbit Ombak.

Sukemi, Adriono, \& Andries, D. W. (2018). Kebijakan Zonasi Percepat Pemerataan Akses dan Mutu Pendidikan. Jakarta: Kementrian Pendidikan dan Kebudayaan .

Ulfah, A. d. (2016). Efektivitas Penerimaan Peserta Didik Baru (PPDB) Melalui Sistem Penerimaan Peserta Didik Online. Jurnal Pasca UM, 4.

Wahab, S. (2016). Analisa Kebijakan: dari Formulasi ke Penyusunan Model Implementasi Kebijakan Publik. Jakarta: Bumi Aksara.

Warsita, B. (2015). Evaluasi Sistem Penerimaan Peserta Didik Baru (PPDB) Online Untuk 